\title{
Performance Pay and Credibility of Performance Measurement: Evidence from CEO Incentive Compensation
}

\author{
Eunjung Yeo*
}

\begin{abstract}
This paper investigates the credibility of performance measurement from the evidence of a link between CEO incentive compensation and CEOs' overstatement of their firms' earnings, measured by stock return sensitivities to firms' earnings announcements. It empirically analyzes whether the stock market response to announced earnings is positively related to the CEO's performance pay. It appears that stock return sensitivities to firms' earnings announcements increased with CEO pay-performance ratio in all earnings categories. Using stock return sensitivities as indicators of a CEO's overstatement of firm earnings, this suggests not only that such overstatements exist, but also that overstatements are more severe among CEOs with high incentive compensation. This suggests that performance measurements based on performance pay are not credible. In addition to tightening market monitoring, regulatory authorities should develop measures that can reduce overstatement, such as making CEO compensation better linked to long-term performance, which is more difficult to embellish.
\end{abstract}

Keywords: CEO incentive compensation, earnings overstatement, stock return sensitivities

\section{INTRODUCTION}

Economists have largely welcomed strong performance pay for managers, such as bonuses, large grants of stocks and stock options, as a good corporate governance

\footnotetext{
* Eunjung Yeo is assistant professor of finance in the School of Business Administration at Chung-Ang University. Email: ejyeo@cau.ac.kr. The author acknowledges Illoong Kwon's valuable suggestions and encouragement, as well as feedback from Charles Brown, Joel Slemrod, Kathy Yuan, Jooyong Jun, Lutz Killian, Chin Te Liu, Russell Lundholm, three anonymous referees, and participants in the University of Michigan Applied Microeconomics Seminar and Economics Summer Seminar. Research grants from Chung-Ang University are also gratefully acknowledged. All remaining errors are the author's.
}

Manuscript received June 20, 2011; out for review June 23, 2011; review completed July 17, 2011; accepted July 26, 2011.

The Korean Journal of Policy Studies, Vol. 26, No. 2 (2011), pp. 137-156.

(C) 2011 by the GSPA, Seoul National University 
practice (Holmstrom, 1982; Holmstrom \& Milgrom, 1991; Gibbons \& Murphy, 1992), finding that higher shares of equity and of equity-based managers' compensation added more value to firms (Mehran, 1995).

Such incentive compensation has been widely used for various classes of employees in various organizations, including for high-level government officials and in many public entities. However, the credibility of performance measurement has often been impaired due to efforts by firms or even public entities to manipulate it when incentive compensation is based on it.

Corporate scandals such as those involving Enron and Worldcom have demonstrated how performance measurement loses credibility when chief executive officers (CEOs) overstate performance to inflate their firms' stock prices. ${ }^{1}$

At Enron, the performance-based pay for the top five executives was extremely high (91.86 percent of total compensation in 1996, 96.65 percent in 2000). ${ }^{2}$ This exceptional level of performance pay probably contributed to the scandals that followed, and this type of performance measurement has lost credibility.

Introduction of such performance measurement based on performance pay might lead to increases both in managers' productive efforts and in overstatements of performance. Theoretical and empirical studies of the effect of performance pay on overstatements by managers have increased. (For empirical studies, see for example Ke, 2002; Gao \& Shrieves, 2002; and Bergstresser \& Philippon, 2003; for theoretical studies, see Dye, 1988; Maggi \& Rodriguez-Clare, 1995; and Crocker \& Slemrod, 2005.)

Overstatement of performance is widespread and a serious problem in many sectors of the economy. ${ }^{3}$ CEOs' overstatement of their firms' earnings can mislead not only investors but also other agents in the market. Thus the detection of firms' earnings overstatements and the examination of their relation to CEOs' performance pay is of importance to a wide variety of agents in the economy, such as investors, auditors, and government regulators. It is especially critical to government regulators, because failing to detect such overstatements has often caused disruption in the financial system and even financial crisis.

This paper examines performance pay and the credibility of performance measurement, based on the evidence for a link between CEO incentive compensation

1. In an article in Business Week, Byrne et al. (2002) argue that "The tyranny of the daily stock price has led to borderline accounting and in some cases, outright fraud. And why not, when every upward tick of the stock means massive gains for option-rich executives?"

2. Source: Forbes 3/22/2002.

3. "Fraudulent accounting for earnings is to everyday business management what tax fraud, a rare practice, is to everyday tax chiseling”-Degeorge, Patel, \& Zeckhauser, 2005. 
and stock return sensitivities to firms' earnings announcements. In particular, it empirically analyzes whether the stock market response to a company's announced earnings is positively related to the CEO's performance pay. A new indicator of a CEO's overstatement of his or her firm's earnings is proposed, earnings surprise sensitivities of stock returns (hereafter stock return sensitivities), which measures the responsiveness (or elasticity) of stock returns with respect to true earnings surprise. It also investigates how CEO tenure affects the level of overstatement of the firm's earnings announcement.

Under the assumption of rational market expectation, the effect of earnings category (for example, good or bad news) determines the direction of movement in stock prices, while the effect of the extent of overstatement determines their sensitivities. For example, when a firm announces earnings that exceed the market's expectation (for example, the consensus of analysts' forecasts), the stock price of the firm will rise regardless of past efforts by the CEO. Since the market knows the level of each effort, the stock price will rise more if the overstatement of earnings has been relatively small than it will if the overstatement has been larger. Similarly, when a firm announces earnings smaller than the market's expectation, the stock price will fall—and it will fall more if the overstatement of earnings has been larger.

The unexpected terms in earnings movement are measured by the true earnings surprise, the gap between actual reported earnings and the consensus forecast by analysts at the time. Thus, one approach is to measure stock return sensitivities, which represent how the stock market responds to a given level of earnings surprise. Table 1 represents theoretical predictions for stock return sensitivities to firms' earnings announcements. For example, if stock return sensitivities are more responsive to an earnings announcement when the earnings surprise is positive, this would imply that CEOs whose pay-performance ratios are high make relatively smaller overstatements in true performance.

Table 1. Theoretical Predictions of Stock Return Sensitivities

\begin{tabular}{c|c|c|c}
\hline Pay-performance ratios & Firm's performance (y) & Relative extent of overstatement & Stock return sensitivities \\
\hline High & High & $\frac{m}{y}:$ Low & (more sensitive) \\
\hline High & Low & $\frac{m}{y}:$ High & (more sensitive) \\
\hline
\end{tabular}

Pay-performance ratios represent the portion of CEO compensation tied to performance. Stock return sensitivities represent the change in stock returns divided by the earnings surprise. They are only observable ex-post. 
Using data from Compustat, Institutional Brokers' Estimate System, the Center for Research in Security Prices, and Compustat Executive Compensation for the period from 1997 to 2007, this study measures stock return sensitivities to firms' earnings announcements, and CEOs' pay-performance ratios, which compare all performancerelated components - such as bonus, net value of stock options exercised, and longterm incentive pay-outs - to total compensation. The empirical results support the theoretical predictions that the relative extent of overstatement by the CEO whose pay-performance ratio is high becomes smaller when the firm's performance is good. In this case, CEOs with high pay-performance ratios are less likely to be involved in overstatement. The resulting stock return sensitivity is high. Similarly, when the firm's performance is bad, CEOs with high pay-performance ratios are more likely to be involved in overstatement. Thus, stock return sensitivity is high in such cases as well.

An important advantage of this approach is that it does not require the direct measurement of overstatement of a firm's earnings. In contrast, many previous studies have used discretionary accrual as a proxy of overstatement (or earnings manipulation in general) and studied how the monetary incentives of managers affect earnings management (e.g., Ke, 2002; Gao \& Shrieves, 2002; Bergstresser \& Philippon, 2003). However, such an approach is subject to criticism and debate about whether accrual is a good proxy (and if so, which type of accrual). ${ }^{4}$ Also, it does not consider the effect of market expectations.

This study's empirical evidence strongly supports that high performance pay exacerbates CEO overstatement. These findings are robust after controlling firm-fixed effects. This suggests not only that there exist overstatements in firms' earnings announcements, but also that overstatements become more severe when the CEO's incentive compensation is high. Thus, performance measurement based on performance pay is not credible. These findings further imply that regulatory authorities should consider developing CEO incentive compensation policies that reduce the likelihood of overstatement, such as tightening market monitoring or at least deferring incentive pay so that it is better linked to long-term performance.

The next section of the paper presents predictions based on a model in which CEOs' incentive to overstate earnings depends on their performance pay and their private information. The following two sections set out the data and methodology on which the analysis is based. Next, the results are discussed. The paper concludes with a discussion of the implications of the results for future research and policy making.

4. For a detailed discussion, refer to the methodology section. 


\section{PREDICTION AND HYPOTHESIS}

Consider an environment in which it is in the interest of shareholders (principal) and a CEO (agent) to improve a firm's earnings under rational expectations of the market. Suppose risk-neutral owners of the firm or shareholders propose a contract consisting of a fixed amount of salary and performance-related terms determined by the stock return to a risk-neutral CEO. Due to this introduction of the stock market into the model, shareholders cannot fully commit to the amount of compensation to be given to the CEO. The CEO initially puts productive effort into improving the firm's earnings, and this action is followed by the opportunity to overstate earnings with costs. 5

This study defines stock return sensitivities with respect to reported earnings per share and investigates how those sensitivities respond to the change in a CEO's payperformance ratio (PPR in the empirical specification). It measures how much the stock return would change in response to unexpected earnings. The unexpected portion of a firm's earnings depends on the reported earnings. However, stock returns associated with a firm's earnings announcement fully reflect any available information about earnings. 6

Thus, for example, a small change in stock returns after a large earnings surprise would mean that stock returns are not sensitive to the firm's earnings announcement. If there is no chance to overstate a firm's earnings, stock return sensitivity is more related to uncertainty about the long-run performance of the firm or anticipated future problems. However, under rational market expectations, firms overstate their performance. In this situation, stock return sensitivity can be linked to the relative extent of overstatement in true performance.

The market uses stock returns to evaluate the effect of a CEO's productive effort. Once the CEO's productive effort is greater than the overstatement effort revealed ex-post, the resulting stock returns are more responsive when the announcements of earnings are considered good. Similar logic can be applied to the case of bad news about earnings.

Next, the study investigated the effect of a CEO's pay-performance ratio (PPR) on stock return sensitivities, which represent the relation between the relative extent of overstatement and the firm's true performance. ${ }^{7}$

5. For a detailed model description, see Kwon and Yeo, 2009.

6. Mathematically, a CEO's earnings report corresponds to the reported performance, $\hat{y}$, in the model, and the stock price corresponds to the market performance, $\tilde{y}$.

7. Assuming overstatement in earnings reports and rational market expectations, the stock 
The sign of the derivative of stock return sensitivities with respect to the payperformance ratio is positive. ${ }^{8}$ It implies that stock returns sensitivities increase with CEO's performance pay. Thus the relative extent of CEO's overstatement is smaller when the firm's announced performance is good and larger when the firm's announced performance is bad.

This result may seem counterintuitive at first glance. The model predicts that as the pay-performance ratio increases, a CEO will overstate more. Thus, one might think that the stock price would respond less sensitively to the announced earnings. However, if the market rationally discounts the announced earnings as the pay-performance ratio increases, the percentage change in stock prices increases because the relative extent of overstatement of earnings determines the percentage change in stock prices. ${ }^{9}$

Therefore, the sign of the derivative in the above with respect to the CEO's payperformance ratio is expected to be positive, which is consistent with the prediction. The resulting hypothesis is as follows:

Hypothesis: Under rational market expectations, stock return sensitivities to a firm's earnings announcement increase with the CEO's pay-performance ratio.

\section{METHODOLOGY}

This section explains how the model predictions given in the previous section were tested using data from Dow Jones Industrial companies. First, stock return sensitivities associated with firms' quarterly earnings announcements were calculated. The study

return sensitivities can be defined as follows:

$$
\eta=\frac{d \tilde{y}}{d \hat{y}} \frac{\hat{y}}{\tilde{y}}=\left[1-\frac{\partial m^{e}(\hat{y} ; \beta)}{\partial \hat{y}}\right] \frac{\hat{y}}{\hat{y}-m^{e}(\hat{y} ; \beta)}=\frac{\frac{\partial m^{e}(\hat{y} ; \beta)}{\partial \hat{y}}}{1-\frac{m^{e}(\hat{y} ; \beta)}{y}}
$$

8. $\frac{\partial \eta}{\partial \beta}>0$ Proof. See the Appendix.

9. In the model, a CEO's overstatement increases his or her firm's true earnings. Intuitively, because the marginal cost of overstatement is increasing, when the firm's earnings are extremely high, the market believes the firm's reported earnings cannot all be driven by the CEO's large overstatement. The market believes that the CEO puts relatively less overstatement efforts in the reported earnings when she has the high pay-performance ratio. In response, CEOs have more incentive to overstate when their firm's true earnings are large, because the market will discount relatively less at the margin. 
used a modified event study in order to measure abnormal stock returns, which reflect how much stock returns gain or lose for a specified time period due to the impact of events (in this case, firms' earnings announcements).

Since it is very difficult to directly measure a CEO's overstatement, the study focused on whether the stock market behaves as if it rationally expects CEOs to overstate their firms' earnings. An important advantage of this approach is that it does not require the direct measurement of overstatement. Many previous studies have used discretionary accrual as a proxy of overstatement (or earnings management in general) and studied how the monetary incentives of managers affect earnings management (e.g., Ke, 2002; Gao \& Shrieves, 2002; Bergstresser \& Philippon, 2003). However, this approach is subject to the criticism that accrual may not be a good proxy (and the question of what type of accrual, if any, to use). For example, Krishnan, Sankaraguruswamy, and Shin (1999) argue that accrual is observable, not only to econometricians, but also to the market. Therefore, if accrual is indeed a good measure of overstatement or earnings management, CEOs cannot deceive the market and will not engage in costly earnings management (see also Schipper, 1989). Thus, they build their tests based on the skewness of the distribution of announced earnings. Similarly, McNichols and Wilson (1988) test earnings management based on the provision for bad debts. Beneish (2001) shows that even when accrual is used as a proxy, there exist wide variations and disagreements on which type of accrual (for example, total accrual or discretionary accrual) should be used. Also, it does not consider the effect of market expectations.

\section{Stock Return Sensitivities}

Event studies were used repeatedly for every firm and every quarter in order to measure abnormal stock returns due to earnings announcements (MacKinlay, 1997). ${ }^{10}$ Firms' quarterly earnings announcements were used as the event. Each event window consisted of two or three days before and after an earnings announcement and was preceded by a 250-day estimation window (Hillmer \& Yu, 1979; Lev, 1989). ${ }^{11}$

10. Event studies are the most commonly used method in economics and finance for measuring the impact of specific events.

11. In most academic event studies, a predetermined number of days are allowed for the stock price to react to an announcement. For example, according to Lev (1989), the appropriate length of event windows for earnings ranges from two days to as much as a year. Hillmer and $\mathrm{Yu}$ (1979) find that the event window should end within hours of the initial announcement. Since this sample is large enough to correct the market's misperception, it is reasonable to assume that the reaction of the stock market to an event lasts two or at most three days based on price volatility and trading volume. 
The market model is employed to calculate stock returns for firm $i$ and quarter $t$ :

$$
R_{i t}=\alpha_{0 i}+\alpha_{1 i} R_{m t}+\varepsilon_{i t}
$$

where is mean return during the normal period, and noise $\varepsilon_{i t}$, has the following properties: $E\left(\varepsilon_{i t}\right)=0, \operatorname{Var}\left(\varepsilon_{i t}\right)=\sigma^{2} \varepsilon_{i t}$. The ordinary least square (OLS) analysis provides unbiased estimates since the size of samples is large enough. The resulting estimates of $\alpha_{0 i}$ and $\alpha_{1 i}$ are used to calculate abnormal returns, indicating how much the stock return rises or falls due to the events compared to mean normal returns. The abnormal returns are the following:

$$
A R_{i t}=R_{\mathrm{it}}-\hat{\alpha}_{0 i}-\hat{\alpha}_{1 i} R_{m t}
$$

where is abnormal return associated with a firm's earnings announcement. Adding abnormal returns for each day of the event window provides cumulative abnormal returns (CAR). They represent patterns that rise, fall, or remain constant when news arrives.

For each event, stock return sensitivities are computed. In response to the unexpected portion of actual reported earnings, the change in cumulative abnormal stock returns between the day before and the day after the announcement (or between the day of the announcement and the day after it) is calculated as follows:

$$
|\eta|=\left|\frac{\% \text { change in stock returns }}{\% \text { change in earnings surpise }}\right|=\left|\frac{\sum_{i=0}^{1} A R_{i}}{\frac{R E P \_F C S T S-M E D \_F C S T S}{a b s\left(M E D \_F C S T S\right)}}\right|
$$

where the denominator measures the portion of announced earnings that are unexpected based on the information provided by the analysts' consensus, while the numerator represents the change in stock returns for the three days around the announcement date compared to the normal period. This measure is used after taking the absolute value because the focus of the study is the responsiveness of stock returns to the earnings surprise.

\section{CEO Pay-Performance Ratio}

In order to define CEO pay-performance ratios, the study uses two different measures. ${ }^{12}$ One, the ratio of incentive-related terms in compensation to total compensation (PPR1), is defined as follows: 


$$
P P R 1=\frac{\text { SOPTEXER }}{S O P T E X E R+B O N U S+S A L A R Y}
$$

where PPR1 represents how much of value is realized from exercising options, compared to the CEO's total compensation and SOPTEXER is the net value realized from exercising options. ${ }^{13}$ BONUS and SALARY are self-explanatory. This relation is more focused on the dollar value increase in the CEO's wealth from exercising options.

The second measure, PPR2, is defined as follows:

$$
P P R 2=\frac{S O P T E X E R+B O N U S+L T I P}{T D C 2}
$$

where LTIP represents long-term payouts and TDC2 is total compensation including options exercised. This pay-performance ratio shows how large a part performancerelated terms are of total compensation - which includes the net value of options exercised (TDC2 in Compustat), consisting of salary, bonus, other annual compensation, total value of restricted stock granted, net value of stock options exercised, long-term incentive payouts, and all other compensation.

Since this study focuses on the degree of interrelationship between the performance-related terms in CEO compensation (pay-performance ratios), all compensation related to $\mathrm{CEO}$ performance is taken into account to define these ratios, including bonus, net value of stock options exercised, and long-term incentive payouts. The study assumes that CEO compensation is evenly spread throughout a year because only annual information on compensation is available. This assumption makes sense because CEO contracts usually last for several years.

12. Ideally, one should measure how much the wealth of a CEO increases for a given increase in stock price. However, due to various unknown restrictions on stock options and stock grants, this study uses the ratio of performance pay to total compensation as a proxy for monetary incentives. The performance-related components are based on those used by Jensen \& Murphy (1990).

13. This represents the difference in value between the exercise price of the options and the market price of the company's stock on the date of exercise. 


\section{DATA AND ESTIMATION METHOD}

\section{Data}

This study examines Dow Jones Industrial Average companies from January 1997 to December 2007 (a period of 11 years). ${ }^{14}$ The total number of companies is 37, but only 30 companies are listed every year; some companies were replaced during the sample period. The total number of observations is 1,169 . Quarterly earnings per share (EPS) data have been collected for the same period. CEO compensation data have been extracted from the executive compensation data in the Compustat Industrial database.

The sample is limited to firms that maintain the same fiscal year end, since CEO compensation relates to the whole year. The pay-performance ratio for a CEO for a specific year is computed based on annual compensation items, so that quarterly payperformance ratios are the same as the corresponding annual pay-performance ratio. Actual (reported) forecasts and analysts' consensus (median) forecasts are calculated based on data from the Institutional Brokers' Estimate System. ${ }^{15}$ Daily stock returns and value-weighted market returns are from the Center for Research in Security Prices, while reported earnings announcement dates have been taken from the Compustat Industrial. Earnings surprise ${ }^{16}$ measures unexpected change in announced earnings under the assumption that the analysts' forecasts are unbiased and provide the best prediction available of actual earnings.

\section{Estimation Method}

OLS regression results are reported using panel data. However, using panel data has the potential to create problems with both serial correlation and heteroscedasticity, with the latter posing a greater concern. With the 11-year sample period, the time series is relatively long; however, with 37 sample firms, the cross section does not

14. Sample firms are limited to Dow Jones Industrial companies because relatively large companies have more detailed data regarding earnings forecasts and CEO compensation. But the sample firms are drawn from a wide range of industries and market capitalizations, which reduces any concern about sample clustering.

15. Since there is no significant difference between the actual forecasts (EPS) from COMPUSTAT and that from the Institutional Brokers' Estimate System, this study uses the actual EPS from the latter database.

16. Earnings surprise is defined as the percentage difference between actual earnings and the consensus (median value) of analysts' forecasts. 
contain much variation in firm characteristics, especially firm size. However, the industry category and the size of firms show meaningful variation across the sample firms. Therefore, robust standard errors and t-statistics are calculated.

In order to solve for the potential endogeneity problem in the degree of CEO incentives, industry dummies are introduced as an instrument variable for the degree of performance pay. In general, CEO compensation is more strongly tied to performance in industries such as information technology and computer software than in manufacturing industries. In this sense, industry dummies are necessarily included in the analysis. Industry classification is not related to the extent of overstatement of earnings.

The study controls for how long the CEO has been in the position on the earnings announcement date (TENURE), and for the category of earnings news (= reported forecasts-consensus forecasts), the size of assets (in logarithm), and market returns as published in the S\&P 500 index.

A regression equation is constructed of the stock return sensitivities on the payperformance ratio in CEO compensation, $\mathrm{CEO}$ tenure, the interaction between payperformance ratio and CEO tenure, and other control variables. Then the following OLS model can be estimated:

$$
\begin{aligned}
\eta_{i t}= & \gamma_{0}+\gamma_{1} P P R_{i t}+\gamma_{2} \text { TENURE }_{i t}+\gamma_{3} E P S S_{-} D I F F_{i t} \\
& +\gamma_{4}\left\{P P R \times \text { TENURE }_{i t}+\gamma_{5} L_{\text {LSSST }}+\gamma_{5} \text { SPRTRN }_{i t}\right. \\
& +\gamma_{6} \text { yrdum }^{*}+\gamma_{7} \text { inddum }^{*}+\varepsilon_{i t}
\end{aligned}
$$

where $\eta_{i t}$ is stock return sensitivities for firm $i$ in period $t$, specifically, the percentage change in stock returns from the normal period to the announcement period divided by the percentage change in earnings surprise for firm $i$ in period $t . P P R_{i t}$ is the payperformance ratio in CEO compensation, on which this paper focuses; TENURE $E_{i t}$ is the number of months that the CEO has been in the position; $\{P P R \times T E N U R E\}_{i t}$ is an interaction term explaining the effect of CEO tenure combined with pay-performance ratios on stock return sensitivities. $E P S_{-} D I F F_{i t}$ is the category of earnings, the difference between reported earnings and consensus earnings; $L A S S T_{i t}$ is the logarithm of the total value of assets of firm $i$ in period $t ; S P R T R N_{i t}$ is the $\mathrm{S} \& \mathrm{P} 500$ index return; and yrdum* $^{*}$ inddum* are dummy variables for years and for different industries, which are categorized by the first two-digit SIC (Standard Industrial Classification) number.

The following firm-fixed-effect model is also estimated for a robustness check:

$$
\begin{aligned}
\eta_{i t}= & \delta_{0}+\delta_{1} P P R_{i t}+\delta_{2} \text { TENURE }_{i t}+\delta_{3} E P S_{-} D I F F_{i t} \\
& +\delta_{4}\{P P R \times T E N U R E\}_{i t}+\xi_{i}+\varepsilon_{i t}
\end{aligned}
$$


for firm $i$ and (quarterly) time $t$ and where $\xi_{i}$ is the firm-fixed effect. The study also controls for firm size, S\&P 500 index return, and category of earnings.

\section{EMPIRICAL RESULTS}

\section{Descriptive Statistics}

Summary statistics for the key variables in the analysis are presented in table 2. Panel A summarizes stock return sensitivities. The average cumulative abnormal returns for $\operatorname{CAR}(0,1)$ and $\operatorname{CAR}(-1,1)$ are 0.28 percent and 0.41 percent, respectively.

Table 2. Summary Statistics

\begin{tabular}{|c|c|c|c|c|}
\hline \multicolumn{5}{|c|}{ Panel A: Stock return sensitivities } \\
\hline Variables & Mean & Std. dev. & Min. & Max. \\
\hline $\operatorname{CAR}(0,+1)(\%)$ & 0.284 & 4.891 & -30.24 & 22.86 \\
\hline $\operatorname{CAR}(-1,+1)(\%)$ & 0.411 & 5.196 & -34.91 & 22.77 \\
\hline REPORTED_EPS & 1.037 & 3.267 & -25.00 & 35.40 \\
\hline CONSENSUS_EPS & 1.088 & 3.284 & -0.455 & 32.20 \\
\hline EARNINGS_SURPRISE (\%) & 3.015 & 86.70 & -1.260 & 2,025 \\
\hline SRSO & 0.906 & 1.630 & 0 & 23.43 \\
\hline SRS1 & 0.962 & 1.723 & 0 & 22.56 \\
\hline \multicolumn{5}{|l|}{ Panel B: CEO compensation } \\
\hline Variables & Mean & Std. dev. & Min. & Max. \\
\hline SALARY & $1,295.61$ & 523.51 & 349.99 & 4,000 \\
\hline BONUS & $2,892.56$ & $2,876.17$ & 0 & $18,484.41$ \\
\hline SOPTEXER & $8,632.42$ & $33,605.59$ & 0 & $569,827.7$ \\
\hline PPR1 & 0.345 & 0.338 & 0 & 0.989 \\
\hline PPR2 & 0.597 & 0.247 & 0.008 & 0.998 \\
\hline TENURE & 68.87 & 69.54 & 6 & 456 \\
\hline SPRTRN (\%) & 0.013 & 1.209 & -6.867 & 5.731 \\
\hline LASST & 10.843 & 1.236 & 7.705 & 14.673 \\
\hline
\end{tabular}

$\mathrm{N}=1,169$.

CARO (or CAR1) represents cumulative abnormal returns for the specific period, $(0,+1)$ (or $(-1,+1))$ due to earnings announcement for a firm-quarter.

Earnings surprise (\%) is the percentage difference between actual reported EPS and analysts' consensus EPS.

SRSO (or SRS 1) measures stock return sensitivities as the cumulative abnormal return of CARO (or CAR1) divided by the amount of earnings surprise.

SOPTEXER is the net value realized from exercising options.

PPR1 represents a CEO's pay-performance ratio defined as the ratio of net value from exercising options to total compensation for a firm-quarter. PPR2 is a CEO's pay-performance ratio defined as the ratio of all incentive terms to total compensation for a firm-quarter.

TENURE represents how many months a CEO has been in the current position.

SPRTRN refers to S\&P 500 index returns, and LASST is log of total value of assets. 
The average earnings surprise in the percentage term is 3.01 and the resulting stock return sensitivities for $\operatorname{CAR}(0,1), \operatorname{CAR}(0,1)$ represent an average of 0.906 and 0.962 , respectively.

Panel B summarizes CEO compensation and determinants affecting stock return sensitivities. The average salary for the CEOs in the sample firms is \$1.296 million with the $\$ 0.523$ million of standard deviation. The average bonus for the CEOs in the sample firms is $\$ 2.892$ million with the $\$ 2.876$ million of standard deviation, which indicates there is great variation of the size of bonus even among CEOs in the Dow Jones Industrial companies. This variation is more prominent in the level of the net value realized from exercising stock options, SOPTEXER with the mean of $\$ 8.632$ million and with $\$ 33.605$ million standard deviation. TENURE has an average of 68.87 months with the maximum of 456 months (or 38 years) and with the minimum of only 6 months.

Table 3 presents the distribution of the sample firms by industry. Although more than half (21) are categorized as manufacturing, the distribution of the sample companies by one-digit SIC code indicates that they are from a wide range of industries, which reduces concerns about sample clustering.

Table 3. Distribution of Sample Firms of One-Digit SIC Code

\begin{tabular}{|c|c|c|}
\hline SIC code & Industry description & Firms in sample \\
\hline 2 & Manufacturing-nondurables & 11 \\
\hline 3 & Manufacturing-durables & 10 \\
\hline 4 & Transportation and utilities & 3 \\
\hline 5 & Wholesale and retail & 5 \\
\hline 6 & Financial services & 5 \\
\hline 7 & Business services & 2 \\
\hline 9 & Nonclassifiable & 1 \\
\hline \multicolumn{2}{|c|}{ Total number of firms } & 37 \\
\hline
\end{tabular}

Table 4 shows that the sample firms increased their use of CEO incentive compensation (bonus and long-term incentive pay) significantly from 1997 to 2005 but not in 2006 and 2007. ${ }^{17}$ In contrast, the average tenure of CEOs clearly decreased from 1997 to 2007 -from 83.7 months to 61.4 months, a 26.6 percent decrease.

17. All the reported long-term incentive payments for 2007 were 0 ; regressions were analyzed with and without these values, but the main results remained the same. 
Table 4. Trends in CEO Incentive Compensation

\begin{tabular}{l|c|c|c|c|c|c|c|c|c|c|c}
\hline & 1997 & 1998 & \multicolumn{1}{c}{1999} & \multicolumn{1}{c}{2000} & \multicolumn{1}{c}{2001} & \multicolumn{1}{c}{2002} & 2003 & \multicolumn{1}{c}{2004} & 2005 & 2006 & \multicolumn{1}{c}{2007} \\
\hline SALARY* & $1,125.43$ & $1,137.10$ & $1,206.91$ & $1,223.25$ & $1,270.72$ & $1,262.51$ & $1,357.33$ & $1,389.37$ & $1,440.13$ & $1,479.00$ & $1,394.33$ \\
\hline BONUS* & $1,928.91$ & $2,119.57$ & $3,084.82$ & $3,074.41$ & $2,503.34$ & $2,390.43$ & $2,945.76$ & $3,649.07$ & $3,914.01$ & $3,744.37$ & $2,450.53$ \\
\hline SOPTEXER* & $7,586.32$ & $24,714.61$ & $9,813.08$ & $16,140.56$ & $8,765.22$ & $2,993.32$ & $4,552.72$ & $5,871.41$ & $3,282.46$ & $5,759.85$ & $6,858.75$ \\
\hline LTIP* $^{*}$ & $1,181.07$ & $1,511.99$ & $1,526.01$ & $1,975.81$ & $1,170.77$ & $1,115.01$ & $1,211.38$ & $1,576.92$ & $1,963.97$ & 471.74 & NA \\
\hline TENURE* & 83.73 & 77.49 & 81.33 & 61.18 & 59.36 & 60.97 & 69.92 & 73.98 & 64.96 & 55.73 & 61.43 \\
\hline PPR1 & 0.4695 & 0.3759 & 0.3770 & 0.3895 & 0.3983 & 0.2718 & 0.2634 & 0.2202 & 0.2133 & 0.4019 & 0.4629 \\
\hline PPR2 & 0.6983 & 0.6445 & 0.6868 & 0.6351 & 0.5842 & 0.6257 & 0.6091 & 0.6187 & 0.6281 & 0.3831 & 0.3585 \\
\hline$N$ & 122 & 104 & 110 & 99 & 99 & 106 & 115 & 120 & 116 & 88 & 90 \\
\hline
\end{tabular}

* Thousands of dollars.

Mean values are reported except for N. SOPTEXER is the net value realized from exercising options; LTIP is the long-term payout; TENURE represents how many months a CEO has been in the current position.

Pair-wise correlations in table 5 show that stock return sensitivities are correlated with CEO's pay-performance ratio and other determinants as expected. Stock return sensitivities are high for companies with CEOs who have high performance pay, which is consistent with the theoretical prediction. CEO tenure is positively related with the size of assets and with pay-performance ratios.

Table 5. Correlation between Variables

\begin{tabular}{l|l|l|l|l|l|l}
\hline & SRS0 & EPS_DIFF & PPR1 & TENURE & LASST & SPRTRN \\
\hline SRS0 & 1.0000 & & & & & \\
\hline EPS_DIFF & 0.0187 & 1.0000 & & & & \\
\hline PPR1 & $0.1163^{* * *}$ & 0.0326 & 1.0000 & & & \\
\hline TENURE & 0.0069 & 0.0213 & $0.2174^{* * *}$ & 1.0000 & & \\
\hline LASST & -0.0196 & $-0.0873^{* * *}$ & $0.1010^{* * *}$ & $0.1829^{* * *}$ & 1.0000 & \\
\hline SPRTRN & 0.0039 & 0.0615 & 0.0012 & 0.0212 & -0.0175 & 1.0000 \\
\hline
\end{tabular}

*** Statistically significant at the 1 percent level.

\section{Ordinary Least Square and Fixed Effect Controlled Analyses}

Table 6 shows the estimated effect of CEO's pay-performance ratio on stock return sensitivities. ${ }^{18}$ Panel A represents ordinary least square analysis. Column 1 presents

18. PPR1, used in this calculation, focuses on an increase in a CEO's wealth that results from 
Table 6. Stock Return Sensitivities to Earnings Announcements

\begin{tabular}{|c|c|c|c|}
\hline \multicolumn{4}{|c|}{ Panel A: Ordinary least square analysis } \\
\hline Dep. var. = SRSO & 1 & 2 & 3 \\
\hline PPR1 & $0.4348^{* * *}(2.98)$ & $0.4771^{* * *}(3.19)$ & $0.2925(1.36)$ \\
\hline TENURE & & $-0.0009(-1.28)$ & $-0.0020 *(-1.74)$ \\
\hline EPS_DIFF & $0.0113(0.39)$ & $0.0123(0.43)$ & $0.0132(0.46)$ \\
\hline PPR $1 \times$ TENURE & & & $0.0025(1.20)$ \\
\hline LASST & $0.0170(0.39)$ & $0.0244(0.55)$ & $0.0215(0.49)$ \\
\hline SPRTRN & $1.445(0.37)$ & $1.607(0.41)$ & $1.437(0.37)$ \\
\hline SIC_2CODE & $0.0045(1.41)$ & $0.0052(1.60)$ & $0.0052(1.60)$ \\
\hline CONST & $0.0350(0.07)$ & $-0.0432(-0.09)$ & $0.0541(0.11)$ \\
\hline Firm-fixed effect & No & No & No \\
\hline $\mathrm{R}^{2}$ & 0.06 & 0.06 & 0.07 \\
\hline \multicolumn{4}{|c|}{ Panel B: Firm-fixed effect analysis } \\
\hline Dep. var. = SRSO & 1 & 2 & 3 \\
\hline PPR1 & $0.3912^{* *}(2.30)$ & $0.4280^{* *}(2.43)$ & $0.2231(0.92)$ \\
\hline TENURE & & $-0.0008(-0.81)$ & $-0.0019(-1.42)$ \\
\hline EPS_DIFF & $0.0104(0.37)$ & $0.0146(0.51)$ & $0.0133(0.46)$ \\
\hline PPR1 $\times$ TENURE & & & 0.0028 (1.22) \\
\hline LASST & $-0.4518^{* * *}(-3.85)$ & $-0.4706^{* * *}(-3.93)$ & $-0.4753^{* * *}(-3.97)$ \\
\hline SPRTRN & $0.0660(0.02)$ & $0.1933(0.05)$ & $0.0156(0.00)$ \\
\hline SIC_2CODE & (omitted) & (omitted) & (omitted) \\
\hline CONST & $5.670 * * *(4.42)$ & $5.918^{* * *}(4.49)$ & $6.036^{* * *}(4.57)$ \\
\hline Firm-fixed effect & Yes & Yes & Yes \\
\hline $\mathrm{R}^{2}$ & 0.03 & 0.03 & 0.03 \\
\hline
\end{tabular}

Standard errors are in parentheses. $\mathrm{N}=1,169$.

SRSO represents stock return sensitivities measured as cumulative abnormal return divided by the amount of earnings surprise; PPR1 represents CEO's pay-performance ratio, defined as the ratio of net value from exercising options to total compensation for a firm-quarter; TENURE is how many months the CEO has been in the position; EPS_DIFF represents the difference between actual reported earnings and analysts' consensus forecasts for a firm-quarter; LASST is the logarithm of total value of assets for a firm; SPRTRN refers to S\&P 500 Index returns.

${ }^{* * *}$ significant at $1 \%$ level; ${ }^{* *}$ significant at $5 \%$ level; * significant at $10 \%$ level

the estimated coefficient of pay-performance ratio of 0.4348 , which is statistically significant at the 1 percent level. Column 2 presents similar results. This finding implies that stock returns are more sensitive to CEOs with higher pay-performance ratios. In other words, CEOs whose pay-performance ratios are higher are likely to make a more

exercising stock options. The empirical results remain the same when PPR2 is used as the pay-performance ratio. Unreported empirical results using CAR1 and PPR1 or PPR2 provide no different results from those in table 6. 
productive effort when their firms' earnings are good, while they are likely to make more overstatements when their firms' earnings are bad. As discussed above, this result is consistent with theoretical predictions that firms overstate their earnings under the assumption of rational market expectations.

Panel B shows firm-fixed effect analysis. These estimates are almost identical to those in panel A, suggesting that the estimated pay-performance ratio effects do not reflect omitted firm-fixed characteristics.

The study also estimates the effect of a CEO's tenure. Panel A, column 3 above presents an estimated coefficient of TENURE of -0.002 , which is statistically significant at the $10 \%$ level. In opposition to the effect of PPR1, a CEO's tenure would decrease stock return sensitivities. One may think that younger CEOs would be more willing to overstate their firm's earnings to improve their own reputation (if they do not get caught), and that older CEOs would not need to overstate because they have already established a reputation. ${ }^{19}$

However, panel B, column 6 shows no significant effect of tenure. The estimated coefficient of the interaction between PPR1 and TENURE is no longer significant with the firm-fixed effect controlled. Perhaps younger CEOs are also less willing to overstate earnings because of the potential long-term damage if they are caught. Then, similar to the effect of PPR1, a CEO's tenure would increase the stock return sensitivities. So these two opposite effects (anticipation of benefit and harm to one's reputation) may offset each other. ${ }^{20}$

For the firm characteristic variable, firm assets, as a proxy for firm size, is negatively related to stock return sensitivities, which implies that larger firms do not or cannot easily overstate earnings, in part because of strong market monitoring.

\section{CONCLUSIONS}

This paper has explored the credibility of performance measurement based on evidence of the link between CEO incentive compensation and CEOs' overstatement of

19. Nam, Wang, and Zhang (2008) argue that managers with a low initial reputation are more likely to speculate early in their careers, and those with a high initial reputation are more likely to hedge. On the other hand, highly reputable managers have minimal career concerns, and they engage in neither hedging nor speculation early in their careers.

20. This result might imply that TENURE may be related to firm-specific factors captured by the firm-fixed effect. Thus, this study checked whether firms offer their own specific length of tenure to CEOs, but the data do not support this possibility. The author appreciates an anonymous referee's comment on this issue. 
their firms' earnings. In order to analyze this relationship, it has proposed a new indicator for overstatement: stock return sensitivities, which measure the responsiveness (or elasticity) of stock returns with respect to true earnings surprise.

The credibility of performance measurement was tested by examining the relationship between a CEO's incentive compensation and stock returns sensitivity to the firm's earnings announcement. Departing from previous studies on CEOs' incentive to overstate their firms' earnings, this study has shed light on the relation between CEO performance pay and the credibility of performance measures.

This study found that stock returns' sensitivity to firms' earnings announcements are likely to be greater when there is higher CEO performance pay. This finding suggests not only that there are overstatements in firms' earnings announcements, but also that overstatements by CEOs with high incentive compensation are likely to be more severe. Thus, performance measurement based on performance pay is not credible. Empirical analysis reveals consistent evidence to support assertions by policy makers that incentives consisting of stock-based compensation and the resulting equity holdings increase the likelihood of overstatement.

This finding further implies that regulatory authorities and policy makers should pay more attention to controlling overstatements, which are induced by CEOs' incentive compensation schemes. For example, increased market discipline would reduce such overstatements, and therefore the authorities should implement policy measures to toughen market monitoring. Also, the authorities should develop other measures that can reduce overstatements, such as deferring incentive pay, so that CEO compensation is better linked to long-term performance, which is more difficult to embellish. Sustained efforts by firms and authorities remain necessary to effectively align compensation structures with efforts to reduce the moral hazard.

Further research is needed on the effect of CEOs' incentive compensation on the extent of overstatement by considering detailed firm effects to control for potential correlated omitted variables pertaining to CEO- and firm-specific characteristics. For instance, Murphy (1985) suggests that contracted CEO compensation depends upon the CEO's opportunity costs, which in turn are related to factors such as education and training, perceived ability, and performance in previous jobs. ${ }^{21}$

21. The board of directors' decision to grant a CEO stock-based compensation is also likely to reflect the effectiveness of alternative corporate governance mechanisms (such as the presence of outside board members and a large number of outside block holders). Unfortunately, detailed information on CEO characteristics and on the structure of the board of directors was not available for analysis during this study. 


\section{APPENDIX: PROOF OF FOOTNOTE 8}

$$
\operatorname{sign}\left\{\frac{\partial \eta(\hat{y} ; \beta)}{\partial \beta}\right\}=\left[-\frac{\partial^{2} m^{e}(\hat{y} ; \beta)}{\partial \beta \partial \hat{y}}\right]\left[1-\frac{m^{e}(\hat{y} ; \beta)}{\hat{y}}\right]-\left[1-\frac{\partial^{2} m^{e}(\hat{y} ; \beta)}{\partial \hat{y}}\right]\left[-\frac{1}{\hat{y}} \frac{\partial^{2} m^{e}(\hat{y} ; \beta)}{\partial \beta}\right]
$$

From the relation of $m^{e}(\hat{y})$

$$
\begin{aligned}
& m^{e}(\hat{y})=\frac{\beta}{k_{m}}\left[1-\exp \left(-\frac{k_{m}}{\beta} \hat{y}\right)\right] \\
& \frac{\partial m^{e}(\hat{y} ; \beta)}{\partial \hat{y}}=\exp \left(-\frac{k_{m}}{\beta} \hat{y}\right) \\
& \frac{\partial^{2} m^{e}(\hat{y} ; \beta)}{\partial \beta \partial \hat{y}}=\frac{k_{m} \hat{y}}{\beta^{2}} \exp \left(-\frac{k_{m}}{\beta} \hat{y}\right) \\
& \frac{\partial m^{e}(\hat{y} ; \beta)}{\partial \beta}=\frac{1}{k_{m}}\left[1-\exp \left(-\frac{k_{m}}{\beta} \hat{y}\right)\right]+\frac{\beta}{k_{m}}\left[-\frac{k_{m} \hat{y}}{\beta^{2}} \exp \left(-\frac{k_{m}}{\beta} \hat{y}\right)\right]
\end{aligned}
$$

Define $\chi=\frac{k_{m}}{\beta} \hat{y}$,

$$
\begin{aligned}
\operatorname{sign}\left\{\frac{\partial \eta(\hat{y} ; \beta)}{\partial \beta}\right\} & \left.=\left[-\frac{\chi}{\beta} e^{-\chi}\right]\left[1-\frac{1}{\chi}\left(1-e^{-\chi}\right)\right]-\frac{1}{\beta}\left[1-e^{-\chi}\right]\left[-\frac{1}{\chi}\left(1-e^{-\chi}\right)-e^{-\chi}\right)\right] \\
& =\frac{1}{\chi \beta}\left(e^{-2 \chi}-2 e^{-\chi}+2 \chi e^{-\chi}-2 \chi e^{-2 \chi}-\chi^{-2} e^{-\chi}+1\right)>0
\end{aligned}
$$




\section{REFERENCES}

Beneish, M. D. 2001. Earnings management: A perspective. Managerial Finance, 27: 3-17.

Bergstresser, D., \& Phillippon, T. 2003. CEO incentives and earnings management. Mimeo, MIT.

Byrne, J. A., et. al. 2002. How to fix corporate governance. Business Week, May 6, 68-81.

Crocker, K. J., \& Slemrod, J. 2005. The economics of earnings manipulation and managerial compensation. Mimeo, University of Michigan.

Degeorge, F., Patel, J., \& Zeckhauser, R. 2005. The market response to earnings thresholds. Mimeo, Harvard University.

Dye, R. A. 1988. Earnings management in an overlapping generations model. Journal of Accounting Research, 26: 195-235.

Gao, P., \& Shrieves, R. E. 2002. Earnings management and executive compensation: A case of overdose of option and underdose of salary? Mimeo, University of Tennessee at Knoxville.

Gibbons, R., \& Murphy, K. J. 1992. Optimal incentive contracts in the presence of career concerns: Theory and evidence. Journal of Political Economy, C, 468-505.

Hillmer, S. C., \& Yu, P. L. 1979. The market speed of adjustment to new information. Journal of Financial Economics, 7(4): 321-345.

Holmström, B. 1999. Managerial incentive problems-A dynamic perspective. Review of Economic Studies, 66: 169-182. (Originally published 1982.)

Holmström, B., \& Milgrom, P. 1991. Multi-task principal-agent analyses: Incentive contracts, asset ownership, and job design. Journal of Law, Economics and Organization, 7: 24-52.

Jensen, M. C., \& Murphy, K. J. 1990. Performance pay and top-management incentives. Journal of Political Economy, 98: 225-264.

Ke, B. 2002. Why do CEOs of publicly traded firms prefer reporting small increases in earnings and long duration of consecutive earnings increases? Mimeo, Pennsylvania State University.

Krishnan, M., Sankaraguruswamy, S., \& Shin, H. S. 1999. Skewness of earnings and the believability hypothesis: How does the financial market discount accounting earnings disclosures? Mimeo, Rutgers University.

Kwon, I., \& Yeo, E. 2009. Overstatement and rational market expectation. Economics Letters, 104: 9-12.

Lev, B. 1989. On the usefulness of earnings and earnings research: Lessons and directions from two decades of empirical research. Journal of Accounting Research 
Supplement, 27: 153-192.

MacKinlay, A. C. 1997. Event studies in economics and finance. Journal of Economic Literature, 35: 13-39.

Maggi, G., \& Rodriguez-Clare, A. 1995. Costly distortion of information in agency problem. Rand Journal of Economics, 26: 675-689.

McNichols, M., \& Wilson, G. P. 1988. Evidence of earnings management from the provision for bad debts. Journal of Accounting Research, 26: 1-31.

Mehran, H. 1995. Executive Compensation Structure, Ownership, and Firm Performance. Journal of Financial Economics, 38: 163-84.

Murphy, K. J. 1985. Corporate performance and managerial remuneration: An empirical analysis. Journal of Accounting and Economics, 7: 11-42.

Nam, J., Wang, J., \& Zhang, G. 2008. Managerial career concerns and risk management. Journal of Risk and Insurance, 75: 785-809.

Schipper, K. 1989. Earnings management. Accounting Horizons, 91-102. 